\title{
Patterns of Social Reactions to COVID-19 Pandemic; Reasons \& Proposed Ways to Overcome
}

\author{
Kaenat Ahmed \\ $2^{\text {nd }}$ Year MBBS Student, CMH Lahore Medical College, Lahore, Pakistan \\ * Corresponding author email: kaenatahmed2000@gmail.com
}

Received: 29 May 2020 / Revised: 09 June 2020 / Accepted: 23 June 2020 / Published: 24 June 2020

\begin{abstract}
This study on the patterns of social reactions to a pandemic has been done amid the spread of COVID-19 globally. Worldwide, everyone reacts differently to every single situation that takes place, especially those as serious as a pandemic. Every individual builds a social reaction unique to his/her concerns. The purpose of this study is to explore the types of reactions people have been showing amid the pandemic from COVID-19, which could help policy makers all over the world to figure out and adapt to the situation according to their own needs and concerns rather than applying a single solution universally. Due to novelty of the topic, and hence limited availability of formal research, this study mostly relies upon reports in print and electronic media about the emerging situation. The study suggests that worldwide, there have been four broad categories of social reactions to a pandemic which include fear, panic, indifference and fatalism. After studying these social reactions, the research comes up with strategies to help resolve these concerns which will eventually help everyone accept the situation and tackle it wisely.
\end{abstract}

Keywords: COVID-19, Coronavirus, Pandemic, Social Reactions, Behaviour, Behavioural Pattern

\section{Introduction}

The recent spread of Coronavirus, popularly known as COVID-19, has come as a significant shock for the well-developed and technologically advanced world leading to a world-wide lockdown in just four months. Since its beginning in December 2019, when it was seen as an epidemic restricted to Wuhan, China, it spread in rest of the world in a matter of days, leading WHO to declare it as a pandemic in March 2020. From its appearance in Wuhan to spreading to the entire globe, it led to two broad types of reactions; first, the reaction of scientists to develop a vaccine, and second, the reaction of governments to restrict its spread by taking preventive measures till availability of the vaccine. While the first reaction proceeded smoothly in accordance with the research norms, the second reaction faced lot of challenges. These challenges came from peoples' resistance to adhere to governments' preventive measures, which were predominantly based on social paradigms people carried for a pandemic or for that matter any calamity. This study gathers information on patterns of social reactions by people and tries to put these patterns in categories, ascertaining underlying reasons for these reactions and suggesting measures to overcome these reactions, not only for COVID-19 pandemic but for all future pandemics that the world may face.

\section{Emergence and Spread of Coronavirus}

Coronavirus belongs to a vast family of viruses that are responsible for illness ranging from the common cold to more severe diseases such as the MERS-CoV (Middle East Respiratory Syndrome) and SARS-CoV (Severe Acute Respiratory Syndrome) (World Health Organization, 2020). COVID-19 (a new strain of the Coronavirus Disease 19) was first reported in Wuhan, China on December 31, 2019. By the end of $20^{\text {th }}$ week, the Coronavirus outbreak had affected a total of 5,018,670 cases, out of which 1,980,306 had recovered and the death toll added up to 325,679 (Worldometer, 2020). The rapid spread COVID-19 managed to set high alert all across the world and led to declaration of a national emergency in the United

\section{Copyright (C) 2020. The Author(s). Published by AIJR Publisher.}

This is an open access article under Creative Commons Attribution-NonCommercial 4.0 International (CC BY-NC 4.0) license, which permits any non-commercial use, distribution, adaptation, and reproduction in any medium, as long as the original work is properly cited. 
Patterns of Social Reactions to COVID-19 Pandemic; Reasons \& Proposed Ways to Overcome

States. Widespread transmission of COVID-19 resulted in a substantial amount of people needing medical attention simultaneously. Social gatherings, shopping, events, schools, universities, and all other places where there could be a throng together experienced gradual desertion. Health providing systems became overloaded along with other important services such as law enforcement, emergency medical services and sectors of transportation systems (Centres for Disease Control and Prevention, 2020).

\section{Social Response to Coronavirus}

The sudden and rapidly evolving situation brought about immense stress and anxiety to many people. Timsit (2020) has reported that people have been fed with a mix of miscalibrated emotion and insufficient knowledge about the COVID-19. She has added how the rapidly increasing percentage of the population affected made people worried more than they needed to be about contracting it and more vulnerable to believing fake claims, adding up to their fear. Along with misinterpretation, fear got adverse when people failed to think of escape routes especially in the presence of news about quarantines and lockdowns. Timsit (2020) has explained how humans have evolved to react imperfectly to any kind of uncertainty and unpredictability because both of these factors made them feel a recognized lack of control over the situation. She added how human beings were made in such a way that they felt the need to protect themselves from threats imposed onto them especially when the threat is so uncertain and not understood well by many. This psychological behaviour leads to people adapting to a typical behaviour. Gurwitch (2020) has elaborated on how people have experienced more anxiety due to the ambiguity of the Coronavirus; she said "There are thousands of people that pass away every year from influenza. But I think because we get a flu shot as protection, there's less anxiety about it". Maxwell (2020) has highlighted that uncertainty is the basis of all anxiety disorders and how the uncertainty of Coronavirus increases anxiety in patients.

The non-profit Crisis Text Line, an intervention hotline, stated that as of 13th March 2020, COVID-19 was mentioned in 15\% of all their conversations. Wetsman (2020) has noted how people started panicking with an increase in the number of cases, leading to everyone targeting grocery stores and pharmacies to stock up on necessities. People started buying more than they needed due to the uncertainty of the lockdown. He added that many grocery stores ran out of hand sanitizers, and many food items like pasta and beans were in short supply due to unnecessary stocking up. Wetsman (2020) wrote in his article that many grocery stores in the US had run out of hand sanitizers due to people panic buying rather than "being prepared" for the pandemic. People in the US had also been stocking up on surgical masks and respirators that were needed more by the health care workers on the frontline than the general public. Cherian (2020) has observed that people started to self-medicate themselves out of fear and panic of an increased number of cases to prevent being infected, many ending up in critical condition died due to false information regarding the medicines.

In a news article published by AP Wire Service, virus rebels from all over France to Florida were seen having a disregard for the lockdown orders by the government. It was said that young Germans held "corona parties" to gather together and cough at older people, as a sign of infecting them and taking the situation lightly. Pinsker (2020) has quoted a bartender in Washington, DC, who noted massive crowds in the bar he worked at and how people neglected the entire pandemic situation. Pinsker (2020) has quoted Fischhoff Baruch, a professor at Carnegie Mellon University, who highlighted how people had the wrong image of the rapid spread of Coronavirus since there were few cases reported in many places. According to him, these people did not know how deceiving the reports were, especially since very few tests were being performed and reported at the time.

The Hajj is the largest annual gathering of Muslims in the world that takes place every year, followed by the Umrah which is a smaller pilgrimage season. According to the Gulf News, most of the pilgrims that gathered in Saudi Arabia for the Umrah seemed unaware about the pandemic and were relaxed about the situation. A middle-aged man from Egypt was found without a mask near Masjid Al Haram and when he was interviewed, he said "We depend on God". Another man from Malaysia was found wearing a mask but 
Kaenat Ahmed, Adv. J Social Sci.; Vol. 7, Issue 1, pp: 54-59, 2020

claimed he had not heard about the Coronavirus and was simply wearing it to protect himself from other diseases. Most of these pilgrims were not aware of the pandemic or they were rather just being careless, stating they had left it on God for their protection without making any effort themselves. Ozalp (2020) said in his article in The Conversation that besides Muslims, other religious groups also took it as a way of God to warn and punish them for the destruction of nature and the environment. This led them to think they should do nothing about it and leave it to God to protect the "righteous". This thought resulted in a decrease in the amount of panic and fear amongst those people, which had caused them to neglect selfisolation and social distancing. Ozalp (2020) added that many Muslims were found against the concept of leaving everything to God and argued that while the emergence of the virus was certainly not in their control but they could control the spread of this virus further by following preventive measures. Shah (2020) has noted that there was nothing wrong with believing in God but not making any effort and ignoring the situation because of their belief is strictly not allowed, especially in Islam. Shah (2020) has added that such an irrational religious approach is a result of ignorance, arrogance, lack of awareness, lack of willingness, and blind faith.

Media has played a huge role in being the cause of this psychological disturbance amid pandemic. Media is immensely motivated to publish fake and alarming news, creating needless worry and panic, without valid proof for an average person to comprehend and realize the importance of the headlines. This is extremely problematic for many people since many lack knowledge about the new COVID-19 compared to other rapidly spreading diseases. An increase in media outlets reporting on the disease has led to a proportionate increase in knowledge, resulting in a problematic increase in public anxieties (Foreign Policy, 2020). In his article, Ritter (2020) has quoted various people highlighting how the information received from media was "not particularly reassuring". He added that reports had been focusing on people getting infected and dying from the virus and not those who have been experiencing only mild symptoms.

As one can see, there have been diverse social reactions to emergence and spread of COVID-19 which have affected society in many ways. Effects of these reactions came as challenges for governments in implementing preventive measures and as barriers for people in adopting self-safety measures. These reactions need to be studied for analysing their causes and taking measures to overcome these reactions for a better handling of a pandemic.

\section{Patterns of Social Reactions - Implications \& Remedial Measures}

A synthesis and analysis of the current literature on social reactions to COVID-19 suggest four broad types of social reactions that have emerged out in this pandemic situation. These are fear, panic, indifference and fatalism.

\subsection{Fear}

American Psychology Association (APA) defines fear as a basic, intense emotion aroused by the detection of imminent threat, involving an immediate alarm reaction that mobilizes the organism by triggering a set of physiological changes (APA Dictionary of Psychology). Fear is closely related to the emotion anxiety, which occurs as the result of threats that are perceived to be uncontrollable or unavoidable (Ohman, 2000). Fear has been one of the most common social reactions to epidemics and pandemics since the human brain has been developed in such a way that uncertainty about anything naturally propagates fear and panic. The rate at which the virus got severe and spread everywhere had been terrifying, leading to many people being fearful about it. This led to an increased focus on the number of deaths due to the Coronavirus than the number of cases recovered, although the latter has been greater so far. People had been staying at home locked up regardless of their situation, those sick due to other diseases and illnesses avoided going to hospitals, worsening their condition.

Fear can easily be reduced by focusing on more reliable and trusted sources of information about the pandemic. The WHO had labelled the on-going situation as a pandemic; this only stated the severity of the spread of the Coronavirus and not how deadly the illness was. Educating people about the extensity of the 
pandemic can have a great difference on the amount of fear that builds in against this virus. Social media has been a major factor in inducing fear and anxiety; people had been updating everyone without knowing how reliable the source was. Decreasing the time spent on social media and focusing mainly on understanding factual statements uploaded on trusted platforms like the Centres for Disease Control (CDC) can help decrease the unnecessary built up of fear and make people focus on being sensibly precautious by practicing preventive measures such as self-isolation and social distancing. Helping people understand the effectiveness of preventive measures could greatly cut down fear.

\subsection{Panic}

American Psychology Association (APA) defines panic as a sudden, uncontrollable fear reaction that may involve terror, confusion, and irrational behaviour, precipitated by a perceived threat (APA Dictionary of Psychology). According to Mayo Clinic, a panic attack is a sudden episode of intense fear that triggers severe physical reactions when there is no real danger or apparent cause (Mayo Clinic). The current edition of the Diagnostic and Statistical Manual (DSM) defines a panic attack as an abrupt and discrete experience of intense fear or acute discomfort (Lilienfeld \& Arkowitz, 2008).

In the current COVID-19 situation, most people who were bombarded with unreliable information and incorrect analysis of the situation or had lack of trust in continuity of civic utilities were found to be worried and targeted with panic attacks due to the pandemic. The spread of informal information created unnecessary worry since most of it consisted of rumours and stories without any trusted source behind it. Grocery stores running out of essential items due to irrational buying, people stocking up on toilet papers, sanitizers and food supplies due to the concern of lengthy quarantine period and people stocking up on surgical masks and respirators, which were needed more by the health care workers on the frontline than the general public, are all indicators of panic. Panic also led to people starting to self-medicate themselves out of fear and panic of an increased number of cases to prevent being infected, ending up in critical condition or deaths due to false information regarding the medicines.

This raises a requirement for governments to provide correct information with evidence to the public, highlighting the number of cases recovered rather than leaving it to media to focus on the number of deaths only. To avoid panic buying, governments must raise awareness and assure people of continued provision of utilities during the pandemic.

\subsection{Indifference}

Cambridge online dictionary defines indifference as lack of interest in someone or something. According to Lillehammer (2014), indifference implies unimportance, this being a matter of the absence of significance of something we might (or might not) take an attitude towards.

Indifference to the threat posed by the virus and its fast spread was obvious in youngsters in France and Florida hosting corona parties and coughing on older people for the sake of fun. Some people had been taking the pandemic extremely lightly and acting as if it were nothing. This was the result of insufficient information provided to them about the spreading pattern and spreading evidence of the Coronavirus. People thought it was still very far since it had not infected anyone in the vicinity without being up-to-date with the severity of the contagion.

To prevent indifference, the foremost step is to educate people on the severity and extent of danger that the pandemic could cause to them. This should be done in parallel with forced shutting down of restaurants, cafes, bars, beaches, and other areas where people could easily gather. Ensuring compliance can be done by imposing heavy fines for non-adherence to orders.

\subsection{Fatalism}

Fatalism is defined as the acceptance of all things and events as inevitable. According to Rice (2018), fatalism is a philosophical doctrine that stresses the subjugation of all events or actions to fate or destiny. 
Kaenat Ahmed, Adv. J Social Sci.; Vol. 7, Issue 1, pp: 54-59, 2020

Many religious groups had said that they did not have to worry about the pandemic since it was from God and everyone who believed in God would be protected by it. Their wrong beliefs and extremist behaviour had been encouraging the further spread of the virus. In Islam, it is extremely prohibited to ignore the situation of the pandemic and make no effort; solely believing in God without making any effort towards the motive is not allowed.

Fatalism can be reduced by educating people about the true essence of their religions. Religious scholars and people of higher authorities in every religion should stay up-to-date with the situation and raise awareness via media about the right beliefs and the right ways of believing in fate. The pandemic can infect anyone, regardless of their age, sex, race and illnesses.

\section{Conclusion}

This study on COVID-19 has indicated four broad types of social reactions that include fear, panic, indifference and fatalism. According to this study, fear and panic were observed in people that had been fed with a mix of unstable emotions and false information. This had led to people stocking-up on unnecessary quantity of resources, believing fake and alarming news posted on social media and harming themselves. Indifference to the Coronavirus was seen mainly among youngsters who believed they weren't going to be infected. They had started gathering in places, which led to further spread of the virus. Fatalism resulted in many people neglecting the pandemic due to their wrong beliefs and blindly relying on God without making any effort. This study showed that everyone showed a different pattern of social reaction to the pandemic and had different concerns causing this difference. Based on the findings, this study has led to a conclusion that governments must take on the responsibility of feeding their people with reliable and trusted information about the pandemic. Moreover, advising people to decrease the time spent on social media and focusing mainly on information uploaded on trusted platforms can help decrease the unnecessary built up of fear. Governments must assure people of continued provision of utilities during the pandemic in order to avoid panic buying. It is important for the government to take strict measures to force isolation and impose heavy fines to stop people from violating orders. To minimize indifference among the public, governments must also educate them on the severity and extent of danger of the pandemic. Furthermore, taking help of religious scholars and people of higher authorities in every religion can reduce fatalism by educating people of every religion about the true essence of religious teachings, therefore reducing the effects of fatalism.

\section{Declarations}

\subsection{Study Limitations}

This study is an opinion survey, and hence cannot be termed as a formal research. It therefore has limited generalizability. A formal research in this area would overcome limitations and make it generalizable.

\subsection{Acknowledgments}

I appreciate and acknowledge the support provided by my colleagues in helping me in writing my first ever research paper.

\subsection{Competing Interests}

The author declared that no conflict of interest exists in this publication.

\section{How to Cite this Article:}

Ahmed, K. (2020). Patterns of Social Reactions to COVID-19 Pandemic; Reasons \& Proposed Ways to Overcome. Advanced Journal of Social Science, 7(1), 54-59. https://doi.org/10.21467/ajss.7.1.54-59 


\section{References}

American Psychology Association Dictionary of Psychology, https://dictionary.apa.org/fear (accessed 9 June 2020)

Cambridge Dictionary, Indifference: Meaning in the Cambridge English Dictionary, https://dictionary.cambridge.org/dictionary/english/indifference (accessed 22 May 2020)

Centres for Disease Control and Prevention (2020) Situation Summary, March 11, 2020, https://www.cdc.gov/coronavirus/2019-ncov/casesupdates/cases-in-us.html (accessed 14 March 2020)

Cherian, D. (2020, March 26) COVID-19: Avoid self-medication and false 'cures' when battling coronavirus, Gulf News, https://gulfnews.com/world/americas/covid-19-avoid-self-medication-and-false-cures-when-battling-coronavirus-1.1585042404259 (accessed 20 May 2020)

Foreign Policy (2020) Coronavirus fears are a national security crisis, March 4, 2020, https://foreignpolicy.com/2020/03/04/coronavirusfears-national-security-crisis-covid-threat-advice/ (accessed 14March 2020)

Gurwitch, R. (2020, February 11) Coronavirus threat escalates fears and bigotry, American Psychological Association, https://www.apa.org/news/apa/2020/02/coronavirus-threat (accessed 22 March 2020)

Kingkade, T. (2020, March 20) Coronavirus is a 'personal nightmare' for people with OCD and anxiety disorders, NBC News, https://www.nbcnews.com/news/us-news/coronavirus-personal-nightmare-people-ocd-anxiety-disorders-n1164066 (accessed 22 March 2020)

Lillehammer, H. (2014) Minding your own business? Understanding indifference as a virtue, Philosophical Perspectives, 28 (1), 111-126

Lilienfeld, S. O. \& Arkowitz, H. (2008) Why do we panic? A better understanding of the path from stress to anxiety to full-blown panic disorder offers soothing news for sufferers, Scientific American, https://www.scientificamerican.com/article/why-do-we-panic/ (accessed 9 June 2020)

Maxwell, C. (2020, March 20) Coronavirus is a 'personal nightmare' for people with OCD and anxiety disorders, NBC News, https://www.nbcnews.com/news/us-news/coronavirus-personal-nightmare-people-ocd-anxiety-disorders-n1164066 (accessed 22 March 2020)

Mayo Clinic, Panic attacks and panic disorders, $4^{\text {th }}$ May, 2018, https://www.mayoclinic.org/diseases-conditions/panic-attacks/symptomscauses/syc-20376021 (accessed 22 May 2020)

Ohman, A. (2000) Fear and anxiety: Evolutionary, cognitive and clinical perspectives, In M. Lewis \& J. M. Haviland-Jones (Eds), Handbook of emotions, pp. 573-593, New York: The Guilford Press

Ozalp, M. (2020, April 2) How coronavirus challenges Muslims' faith and change their lives, The Conversation, https://theconversation.com/how-coronavirus-challenges-muslims-faith-and-changes-their-lives-133925 (accessed 19 April 2020$)$

Pinsker, J. (2020, March 17) The people ignoring social distancing, The Atlantic, https://www.theatlantic.com/family/archive/2020/03/coronavirus-social-distancing-socializing-bars-restaurants/608164/ (accessed 19 April 2020)

Rice, H. (2018) Fatalism. In Zalta, Edward N. (Ed), Stanford encyclopaedia of philosophy, Stanford University, Center for the Study of language and information (accessed 22 May 2020)

Ritter, M. (2020) How people perceive and manage risks like coronavirus, Insurance Journal, March 9, 2020. https://www.insurancejournal.com/news/national/2020/03/09/560556.html (accessed 14 March 2020)

Saudi Arabia: Prudence mixes with fatalism over MERS (2013, October 2013) Gulf News, https:/gulfnews.com/world/gulf/saudi/saudiarabia-prudence-mixes-with-fatalism-over-mers-1.1242234 (accessed 19 April 2020)

Shah, Z. A. (2020, March 27) Fight not just coronavirus but also irrationality and fatalism, Kashmir Reader, https://kashmirreader.com/2020/03/27/fight-not-just-coronavirus-but-also-irrationality-and-fatalism/ (accessed 19 April 2020)

Timsit, A. (2020, March 9) The psychology of coronavirus fear and how to manage it, Quartz, https://qz.com/1812664/the-psychology-ofcoronavirus-fear-and-how-to-overcome-it/ (accessed 14 March 2020)

Virus rebels from France to Florida disregard lockdown practices (2020, March 22) Fox 6 Now, https://fox6now.com/2020/03/22/virusrebels-from-france-to-florida-disregard-lockdown-practices/ (accessed 24 March 2020)

Wetsman, N. (2020, March 10) Fearful reactions to the new coronavirus can put lives at risk, The Verge, https://www.theverge.com/2020/3/10/21172988/coronavirus-fear-reactions-virus-ebola-cdc-covid19-panic-precautions (accessed 20 May 2020)

World Health Organization (2020) Coronavirus, $22^{\text {nd }}$ March, 2020, https://www.who.int/emergencies/diseases/novel-coronavirus-2019 (accessed 22 March 2020)

Worldometer (2020) Coronavirus Cases, May 20, 2020, https://www.worldometers.info/coronavirus/ (accessed 20 May 2020)

Publish your research article in AIJR journals-

- Online Submission and Tracking

- Peer-Reviewed

- Rapid decision

- Immediate Publication after acceptance

- Articles freely available online

- $\quad$ Retain full copyright of your article.

Submit your article at journals.aijr.in

\section{Publish your books with AIJR publisher-}

- Publish with ISBN and DOI.

- Publish Thesis/Dissertation as Monograph

- Publish Book Monograph.

- $\quad$ Publish Edited Volume/ Book.

- Publish Conference Proceedings

- Retain full copyright of your books.

Submit your manuscript at books.aijr.org 